\title{
ICARE Approach for Designing Online Learning Module Based on LMS
}

\author{
I Kadek Suartama, Luh Putu Putrini Mahadewi, Dewa Gede Hendra Divayana, and Muhammad Yunus
}

\begin{abstract}
Online learning started with the emergence of internet technology and has been increasingly used during the COVID-19 pandemic. However, it has raised many problems, such as limitations in presenting material (monotonous and uninteresting), building activeness and difficulty creating interaction between lecturers and students and between students. Moreover, online learning is more stressful than regular classroom sessions because students have to study alone. The absence of clearly structured learning steps also makes it difficult for them to focus. Therefore, this research aims to develop an independent online learning module with a structured and systematic flow called Introduce, Connect, Apply, Reflect and Extend (ICARE) based on the Learning Management System (LMS). Furthermore, it determines the eligibility of the module using a Research and Development (R\&D) for Education design involving Analysis, Design, Development, Implementation and Evaluation. All stages resulted in an eligible online module with an LMS-based ICARE flow in the Learning Media course.
\end{abstract}

Index Terms-ICARE approach, online learning module, LMS.

\section{INTRODUCTION}

Learning systems worldwide, including in Indonesia, were forced to change completely during the Covid-19 pandemic. Before the pandemic, certain schools, colleges and training institutions rarely conducted online learning [1], [2]. However, this changed during the pandemic because schools and universities have implemented many online-based learning policies [3], [4]. This is a quick response to minimise the Covid-19 transmission.

Online learning is practical and flexible because it is conducted anywhere [5]-[7]. However, it causes many unique problems for lecturers and students during the pandemic. Most lecturers and students are not ready for online learning because they are unfamiliar with its technology and strategies [8]. Irfan et al. [9] stated that the challenges faced in online learning include limitations in material presentation (monotonous and uninteresting), building activeness and difficulty creating interaction between lecturers and students and among students. Moreover, online learning is more stressful than regular

Manuscript received August 27, 2021; revised September 26, 2021. This work was supported by a Universitas Pendidikan Ganesha grant through DIPA BLU Number: SP DIPA-023.17.2.677530/2021 Revision 2 dated 10 March 2021 and in line with the Contract Number: 494/UN48.16/LT/2021.

I Kadek Suartama, Luh Putu Putrini Mahadewi, and Dewa Gede Hendra Divayana are with Universitas Pendidikan Ganesha, Bali, Indonesia (e-mail: ik-suartama@undiksha.ac.id,_ lpp-mahadewi@undiksha.ac.id, hendra.divayana@undiksha.ac.id).

Muhammad Yunus is with Universitas Syiah Kuala, Banda Aceh, Indonesia (e-mail: yunus.msalem@unsyiah.ac.id). classroom sessions because students have to study alone. The absence of structured and systematic learning steps also makes it difficult to focus [10]. Online content is theoretical and mediocre and does not allow students to practice and study effectively [11]. Furthermore, mastery learning cannot be completed online [12].

The previous studies are a reference in overcoming the obstacles lecturers and students face in online learning to make it more interesting and meaningful. Lecturers must innovate in new learning methodologies that they did not prepare before, by integrating technology as one of the main tools to convey knowledge into strategies and teaching materials [13]. In addition, pedagogy is a determining factor in intentions, behaviour and success in online learning. It includes clear and structured learning strategies, the provision of richer content or teaching materials and an environment that improves student performance [14]. Students learn in different ways with various modalities. Providing various media options for students and giving clear learning steps ensure that they continue learning [15]. However, systematic planning is needed to determine and define these pedagogical aspects in a module design.

Learning modules are teaching materials arranged systematically and attractively. They include material content, methods and evaluations for independent use to achieve the expected competencies [16]. Learning modules are currently divided into three categories. The first category is the conventional or physical teaching materials, such as books and other prints. The second category comprises electronic teaching materials accessed through electronic devices, such as cellphones, tablets, PCs and laptops, that store the module. The third category consists of online teaching materials accessed through electronic devices anytime and anywhere, provided that there is an internet network [17].

Online learning modules are teaching materials arranged systematically, measurable, attractive and easily understood by users. They are accessible and used without space and time barriers, provided that there is an internet network. Therefore, they are accessed using gadgets such as cellphones, tablets and PCs or laptops. Moreover, online learning materials are built from various meaningfully integrated resources [18]. In line with this, online modules enable interactive learning, assessment and adaptive feedback [17]. They are designed to support students' independent learning in diverse environments [19].

The transition from face-to-face to online teaching materials is a challenge because lecturers are no longer present in real-time to assess and direct students' learning. Therefore, its effectiveness strongly correlates with the module organisation and the clarity of the written information provided and the learning steps [20]. Research in the field of development and application of online learning 
modules has been carried out in recent times. However, some researchers found problems in the application of online learning modules. Smart and Cappel [21] found that online learning modules that are full of long content of learning materials make students bored and tired in learning. Moradi et al. [22] stated that students do not like online learning modules whose contents are only exposure to material and practice questions, it will spend too much time for students to be able to understand the learning material, and it is not effective and efficient. They suggest that online learning modules should be structured in a simple, complete, interactive, systematic manner by presenting steps/scaffolding that can lead students to learn. It is necessary to design modules with the structured or systematic steps applicable in large classes and promote and enable students to reflect on the subject content and formulate their thoughts before sharing them privately.

Introduce, Connect, Apply, Reflect and Extend (ICARE) is a learning model showing systematic and structured learning steps. This model is applicable in making and directing students to be more active in learning and draw conclusions from the lessons [23]. Furthermore, it ensures that students apply what they have learned, making learning more meaningful [24]. Online modules are developed using the Learning Management System (LMS) [15]. Matthew Perkins [25] stated the benefits of LMS that allow lecturers to easily send assignments, lesson plans, announcements and other learning documents. This research uses the Moodle LMS because it increases students' involvement in online learning and positively influences their thinking and innovation skills [26]-[29].

\section{RESEARCH METHOD}

\section{A. Research Design}

This study uses the Research and Development (R\&D) for Education method to produce an online learning module and test its eligibility [30]. The steps taken in developing the module with an LMS-based ICARE flow were adapted from the development model proposed by Lee and Owens [31]. They include Analysis, Design, Development, Implementation and Evaluation (ADDIE) stages. This model is used because it has been tested and is complete and simple.

\section{B. Research Procedure}

Referring to the research design and development models selected, the procedure for developing an LMS-based online module with ICARE flow is described in Table I.

\section{Product Validation and Trial}

The developed product's eligibility is determined through validation by one material or content expert (lecturer for Learning Media course) and one media expert (doctorate in educational technology). Furthermore, the product is tested on 64 Universitas Pendidikan Ganesha students taking the Learning Media course. The data obtained from the validation and trial activities are then analysed and used to improve or perfect the developed product.

\section{Data Collection Instrument}

A questionnaire was used in the product validation and trial activities. The right data were obtained using quality instruments that explore what is desired. The quality instruments were obtained by analysing documents, making specification tables (grid), consulting with experts (material and media) and colleagues and writing instruments.

TABLE I: STEPS FOR DEVELOPMENT OF ONLINE MODULE WITH LMS-BASED ICARE FLOW

\begin{tabular}{|c|c|c|}
\hline No. & Step & Activity \\
\hline 1. & Analysis & $\begin{array}{l}\text { a. Need assessment, identifying problems causing } \\
\text { unoptimal learning processes and outcomes } \\
\text { b. Front-end analysis, identifying student } \\
\text { characteristics, infrastructure and facilities as } \\
\text { online learning supports and environment } \\
\text { conditions } \\
\text { c. Conducting instructional analysis, including } \\
\text { mapping of competencies or learning objectives } \\
\text { to be mastered by students }\end{array}$ \\
\hline 2. & Design & $\begin{array}{l}\text { a. Determining the need for computer equipment } \\
\text { (hardware and software) } \\
\text { b. Determining learning materials or resources } \\
\text { and strategies or activities } \\
\text { c. Designing and mapping the resources and } \\
\text { activities in the LMS into the ICARE stage in } \\
\text { the form of a programme mapping }\end{array}$ \\
\hline 3. & Development & $\begin{array}{l}\text { a. Creating an online module this step consists of: } \\
\text { (1) Creating a portal by obtaining a server or } \\
\text { Webhosting, choosing a category and } \\
\text { creating and elevating user status } \\
\text { (2) Creating a Learning Media course with } \\
\text { steps: 1) create and change course settings, } \\
\text { 2) enter resources (Page, Label, File, Book, } \\
\text { Folder, IMS Content Package, URL) and } \\
\text { 3) create an activity (Lesson, Chat, Forum, } \\
\text { Assignments, Feedback, Choice, Database, } \\
\text { Glossary, Quiz, Survey, Wiki, Workshop, } \\
\text { SCORM, LTI/External Tool) } \\
\text { b. Product validation by material or content and } \\
\text { media experts } \\
\text { c. Conducting product revision }\end{array}$ \\
\hline 4. & Implementation & Conducting trials on students \\
\hline 5. & Evaluation & Final revision and product evaluation \\
\hline
\end{tabular}

TABLE II: GRID OF LEARNING MATERIAL ASSESSMENT INSTRUMENT

\begin{tabular}{ll}
\hline \hline Assessed aspect & Indicator \\
\hline Material Aspect & a. Suitability of the material with the competency \\
& formulation \\
& b. Concept truth \\
& c. Order of material presentation \\
& d. Suitability of the given example \\
& e. Adequacy/completeness of materials \\
& f. Material updates \\
Learning Aspect & a. Clarity of learning objective formulation \\
& b. Accuracy of learning indicators \\
& c. Giving motivation \\
& d. Giving training \\
eanguage & e. Suitability of images, videos to clarify the \\
Aspect & a. Suitability of language with student development \\
& b. Spelling and grammar accuracy \\
& c. Accuracy of terms \\
& d. Language simplicity \\
e. Ability to arouse students' curiosity
\end{tabular}

The questionnaire filled out by the material expert is prepared based on the theory of principles and perspectives for designing learning software [32]. Furthermore, the questionnaire filled out by the media expert adapts to comprehensive standards or rubrics for online learning design [33]. Meanwhile, the questionnaire filled out by students in the trial activity is prepared based on assessing the material and media experts. This involves selecting the statements or questions relevant to students of the developed product users. This questionnaire has open-ended and 
closed-ended questions or statements. Open-ended questions ask for opinions or suggestions from experts and students on the developed product, whereas closed-ended statements are prepared using a 5-point Likert scale. Tables II and III present the instrument grids of material and media experts.

TABLE III: GRID OF ONLINE LEARNING MEDIA ASSESSMENT INSTRUMENT

\begin{tabular}{llll}
\hline \hline Main standards & Specific standards & \\
\hline Course opening & a. Description & e. Integrity \\
& b. Behaviour & f. Technical \\
& c. Role & & competences \\
Instructional & d. Accessibility & g. Ownership \\
resources for & a. Openness & d. Application \\
teaching and & b. Provision & e. Variety \\
learning & c. Entitlement & f. Academic integrity \\
Interaction and & a. Peer learning & c. Management \\
community & b. Fostering & & \\
Learner support & a. Academic & c. Administrative \\
Technology & b. Instructional & d. Technical \\
design & a. Interface & d. Investment \\
Course closing & b. Access & e. Authentication \\
& c. Centricity & f. Management \\
Assessment of & b. Archiving & c. Resolution \\
learning & b. Measurement & c. Management \\
Instructional & a. Academic & c. Feedback \\
design cycle & b. Administrative &
\end{tabular}

\section{E. Data Analysis Technique}

The research used qualitative data, comprising criticisms, inputs and suggestions from validators and students collected and summarised for product improvements. In addition, it used quantitative data in the form of scores obtained from each instrument item. The descriptive statistical analysis technique provided the value or quality of the developed online module. The scores obtained were added up, averaged and converted using a 5-scale criterion-referenced test table [34], as shown in Table IV.

TABLE IV: CONVERSION OF SCORES INTO VALUES ON A FIVE SCALE

\begin{tabular}{lll}
\hline \hline \multicolumn{1}{c}{ Score } & Calculation & Value/category \\
\hline $\mathrm{X}>\bar{X}_{i}+1.80 \mathrm{Sbi}$ & $\mathrm{X}>4.21$ & Very good \\
$\bar{X}_{i}+0.60 \mathrm{Sdi}<\mathrm{X} \leq \bar{X}_{i}+1.80 \mathrm{Sdi}$ & $3.40<\mathrm{X} \leq 4.21$ & Good \\
$\bar{X}_{i}-0.60 \mathrm{Sdi}<\mathrm{X} \leq \bar{X}_{i}+0.60 \mathrm{Sdi}$ & $2.60<\mathrm{X} \leq 3.40$ & Quite good \\
$\bar{X}_{i}-1.80 \mathrm{Sdi}<\mathrm{X} \leq \bar{X}_{i}-0.60 \mathrm{Sdi}$ & $1.79<\mathrm{X} \leq 2.60$ & Bad \\
$\mathrm{X} \leq \bar{X}_{i}-1.80 \mathrm{Sdi}$ & $\mathrm{X} \leq 1.79$ & Very bad \\
\hline \hline
\end{tabular}

\section{Description:}

Ideal mean $\left(\bar{X}_{i}\right): 1 / 2 \times$ (maximum score + minimum score $)$

Ideal standard deviation $(\mathrm{Sdi}): 1 / 6 \times$ (maximum minimum score)

Maximum score : 5

Minimum score: 1

$$
\begin{array}{ll}
\bar{X}_{i} & : 1 / 2 \times(5+1)=3 \\
\text { Sdi } & : 1 / 6 \times(5-1)=0.67 \\
X & : \text { Actual score }
\end{array}
$$

The following formula is used to find the mean score in assessing the developed product:

Description:

$$
\bar{X}_{i}=\frac{\sum X}{n}
$$

$\bar{X}_{i}=$ Mean score

$\sum X=$ Total score $\mathrm{n}=$ Number of validators/respondents

A minimum 'Good' eligibility value is determined through assessment by the material and media experts. The developed online learning module is eligible for application when the final (overall) assessment receives a 'Good' score from the experts.

\section{RESUlT AND DiscUSSION}

\section{A. Results of Analysis Phase}

The results of the analysis activities consist of data regarding 1) student characteristics, 2) course characteristics and 3) learning environment conditions. The results of this analysis activity are qualitative data obtained through observation, documentation studies and questionnaires filled out by students.

Universitas Pendidikan Ganesha students almost all have the ability to operate information and communication technology devices, most of them also have these devices such as laptops, tablets and smartphones that they have also used in learning, even some students have more than one device. They prefer to find information, study, collect assignments and discuss through their electronic devices.

The learning media course with 3 credits has a very broad material coverage consisting of material that is theoretical in nature and empirically practical. The competencies that must be achieved in this course are that students have knowledge, skills and attitudes in the fields of design, development, utilisation, evaluation and study of media in learning. Seeing the wide proportion of teaching materials consisting of material in the form of theory and practice, a systematic delivery strategy is needed that can guide students to study outside of learning hours on campus and they can easily do it themselves. Online learning modules with clear procedural steps are considered appropriate in the characteristics of these courses.

With respect to environmental and infrastructure support, Universitas Pendidikan Ganesha already has several computer laboratory units with an adequate number of PCs, Wi-Fi is available for internet connection, and almost all lecturers and students hold information and communication technology devices and have the ability to use them. In addition, most of the lecturers and students have subscribed to cellular data packages to obtain internet access outside the campus area. This condition can be a driving force for the application of learning using online learning modules.

\section{B. Online Learning Module Design}

The online module design with an ICARE flow based on the Moodle LMS displays digital learning stages and materials. The learning steps are the ICARE model stages, consisting of introduction, connection, application, reflection and extend. Materials include document (doc, pdf, xls, txt), presentation (ppt), picture (jpg, gif, png), video (mpg, wmv), sound (mp3, au, wav) and animation (swf, gif). The learning steps and materials are arranged as a programme mapping for easy accessibility and use when developing online modules. In this regard, programme mapping is a table with learning steps and materials, where each component has an interconnected link [6]. The programme mapping of the online module with ICARE flow based on Moodle LMS 
contains a description of learning steps, types of materials and Moodle LMS features, comprising resources and

activities, as shown in Table V.

TABLE V: PROGRAMME MAPPING OF ONLINE LEARNING MODULE WITH ICARE FLOW BASED ON MOODLE LMS

\begin{tabular}{|c|c|c|c|}
\hline \multirow{2}{*}{ ICARE flow } & \multirow{2}{*}{$\begin{array}{c}\text { Type of learning } \\
\text { material }\end{array}$} & \multicolumn{2}{|c|}{ Moodle LMS features } \\
\hline & & Resource & Activities \\
\hline $\begin{array}{l}\text { Introduction } \\
\text { - Providing an understanding of the lecture content to students. } \\
\text { - This section explains the course objectives and what is to be achieved by the } \\
\text { course. }\end{array}$ & $\begin{array}{l}\text { - Document (pdf) } \\
\text { - Presentation (ppt) }\end{array}$ & $\begin{array}{l}\text { - Page } \\
\text { - File }\end{array}$ & $\begin{array}{l}\text { - Lesson } \\
\text { - Forum }\end{array}$ \\
\hline $\begin{array}{l}\text { Connection } \\
\text { - Connecting new teaching materials with something familiar to students. } \\
\text { - Conducting simple brainstorming exercises to understand what students } \\
\text { already know. } \\
\text { - Students tell what they remember from previous lectures or by developing } \\
\text { activities they are able to carry out themselves. } \\
\text { - Lecturers connect students' prior knowledge with new information through } \\
\text { presentations or simple explanations. }\end{array}$ & $\begin{array}{l}\text { - Document (doc, } \\
\text { pdf) } \\
\text { - Presentation (ppt) } \\
\text { - Picture (jpg, png) } \\
\text { - Video (mpg) }\end{array}$ & $\begin{array}{l}\text { - Book } \\
\text { - File } \\
\text { - URL }\end{array}$ & $\begin{array}{l}\text { - Lesson } \\
\text { - Assignments } \\
\text { - Chatting } \\
\text { - Feedback } \\
\text { - Google meet } \\
\text { - Messages } \\
\text { - Assignments } \\
\text { - Feedback }\end{array}$ \\
\hline $\begin{array}{l}\text { Application } \\
\text { - Students are allowed to practice and apply new knowledge and skills. } \\
\text { - Students work individually, in pairs or in groups to complete real activities } \\
\text { or solve problems using the new information and skills acquired. }\end{array}$ & $\begin{array}{l}\text { - Document (pdf) } \\
\text { - Presentation (ppt) } \\
\text { - Animation (swf) } \\
\text { - Video (mpg) } \\
\text { - Multimedia (exe) }\end{array}$ & $\begin{array}{l}\text { - File } \\
\text { - URL } \\
\text { - IMS content } \\
\text { package }\end{array}$ & $\begin{array}{l}\text { - Forum } \\
\text { - Assignments } \\
\text { - Chatting } \\
\text { - Feedback } \\
\text { - Google meet } \\
\text { - Messages } \\
\text { - Assignments } \\
\text { - Feedback }\end{array}$ \\
\hline $\begin{array}{l}\text { Reflection } \\
\text { - Students make presentations or write about what they have learned from the } \\
\text { summary of learning outcomes. } \\
\text { - Giving exploratory quizzes/questions to students with several choices } \\
\text { adapted to conditions. }\end{array}$ & $\begin{array}{l}\text { - Document (pdf) } \\
\text { - Presentation (ppt) }\end{array}$ & $\begin{array}{l}\text { - File } \\
\text { - URL } \\
\text { - Label } \\
\text { - Page }\end{array}$ & $\begin{array}{l}\text { - Lesson } \\
\text { - Feedback } \\
\text { - Workshop } \\
\text { - Assignments } \\
\text { - Quiz }\end{array}$ \\
\hline $\begin{array}{l}\text { Extend } \\
\text { - Students read additional teaching materials, assignments or exercises to } \\
\text { strengthen and expand the completed subject matter. }\end{array}$ & $\begin{array}{l}\text { - Document (pdf) } \\
\text { - Presentation (ppt) }\end{array}$ & $\begin{array}{l}\text { - File } \\
\text { - URL } \\
\text { - Label } \\
\text { - Page }\end{array}$ & $\begin{array}{l}\text { - Lesson } \\
\text { - Feedback } \\
\text { - Assignments }\end{array}$ \\
\hline
\end{tabular}

\section{Final Product}

The online module as the final product of this development research is accessed at https://elearning.undiksha.ac.id/course/view.php?id=5208. The Learning Media course as the research object is categorised in the Second-semester Educational Technology Study Programme. This course consists of six modules with different topics on learning media. They include basic concepts, classification, characteristics, management, selection and development of learning media. The display of module 6 is shown in Fig. 1.

Fig. 1 shows that each module follows the systematic stages of the ICARE flow. The Introduction consists of learning instructions, basic competencies, indicators, learning objectives and learning materials. It provides students with an understanding of how to learn, the competencies to be achieved and the content of learning materials. This introduction is built by utilising the Lesson feature of the LMS, which allows students to navigate each page regularly. The learning materials section contains files (pdf, ppt, mpg, swf, exe, etc.) according to each module's topic. Connection is performed synchronously through the web meeting feature (video conference). This stage provides apperception by connecting new teaching materials with something familiar to students. In this case, connection involves holding a simple brainstorming exercise to understand students' knowledge and asking them to state what they remember from the previous lecture. The lecturer then connects the students' prior knowledge with new information through presentations or simple explanations. Furthermore, Application is conducted to allow students to practice and apply new knowledge and skills. Students work individually, in pairs or in groups to complete activities or solve real problems using the new information and skills acquired. Additionally, activities at this stage are facilitated by Student Worksheets with case-based (module 2) and project-based learning (module 6) methods using the assignment LMS feature. Reflection is conducted to check or ensure what students have learned by presenting a learning outcome summary. This stage utilises web conferences and gives students exploratory quizzes or questions with several choices adapted to conditions. The features used in the LMS are web meetings (video conference) and quiz. Subsequently, Extend is conducted to strengthen and expand the completed subject matter by reading additional teaching materials, assignments or exercises using the URL LMS feature.

The developed online module has shown the systematic and structured learning steps through which students study the material independently according to their preferences. Furthermore, they expand their knowledge by researching what they learn from learning activities and become responsible for understanding [35]. The learning stages in this module contain an invitation to make students more familiar with the material being studied. In addition, it stimulates the emergence of their critical attitude towards the material. This means that ICARE accommodates many applications of the topics studied in everyday life. Additionally, it provides assignments that require students to find answers through various resources [36].

\section{Product Eligibility}

After internal testing to ensure the product runs smoothly, it is evaluated through validation by material and media experts and trial to students. Fig. 2 presents the expert validation and product trial results. 


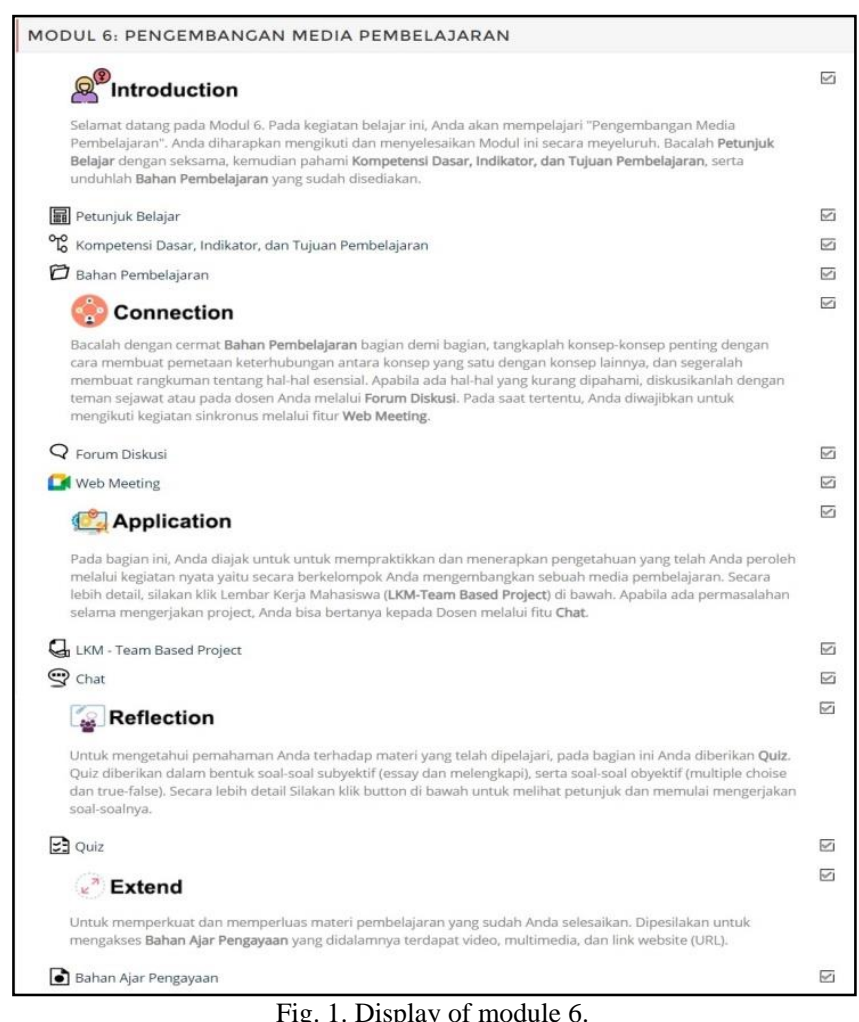

Fig. 1. Display of module 6.

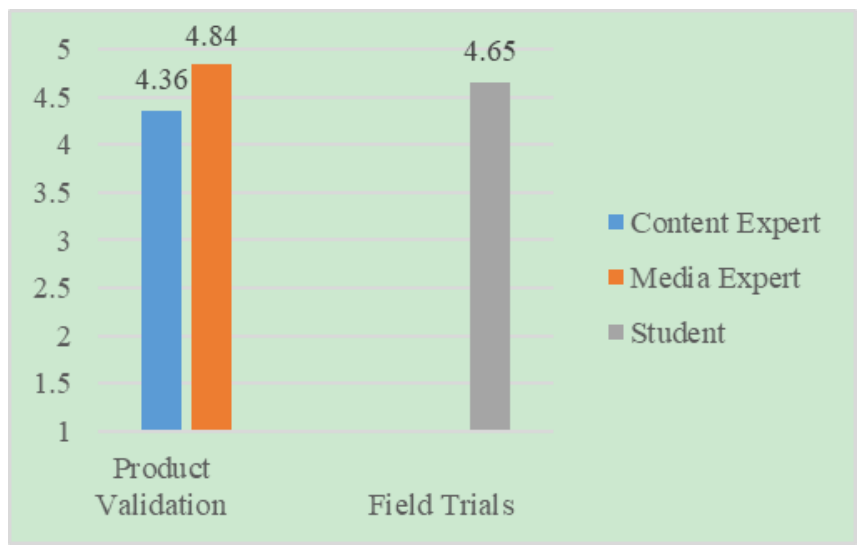

Fig. 2. Results of product validation and field trials.

The data in Fig. 2 show that the mean score for the overall product assessment by the content expert is 4.36 . This figure is 'Very Good' according to the conversion table of quantitative to qualitative data on a five scale. Therefore, the material developed is eligible to be applied in learning. Moreover, two revisions or improvements were made based on suggestions from the material expert. First, advanced material obtained from learning resources was added by utilisation. Second, students were presented with problem-or project-based learning materials that enable them to think critically and creatively.

The mean score for the overall product assessment by the media expert is 4.84. This figure is 'Very Good' according to the conversion table of quantitative to qualitative data on a five scale. Therefore, the developed media is eligible for application in learning. Similarly, three revisions or improvements were made based on suggestions from the media expert. First, various learning resources were added to accommodate different student modalities. Second, instructions were added to each module to assist students in self-study. Third, discussion forums were added to train students in critical, creative thinking and fostering communication or collaborative skills.

The mean score for the overall online module assessment in the learning media course by students is 4.65 . This figure is 'Very Good' according to the conversion table of quantitative to qualitative data on a five scale. Therefore, the product developed is eligible for application in learning. Based on student comments in the product trial, learning becomes more flexible because online modules are accessed anytime and anywhere. Furthermore, systematic learning steps help accelerate the understanding of module content. Students also admitted that enrichment materials provide broader insight into the subject matter. They evaluate the learning progress from feedback and grades provided immediately by the lecturer. Moreover, online modules are easier to use and highly accessible, making learning more efficient.

The assessment by experts and students in the 'Very Good' category is due to the steps and aspects considered and used in developing this online learning module. The online module with an LMS-based ICARE flow in this Learning Media course was developed through five stages, namely, ADDIE. This process was quick and smooth because it is based on the pre-made plans and supported by the readiness of the required materials according to the analysis results.

The eligibility of an online module with an LMS-based ICARE flow in the Learning Media course is achieved because the presentation follows structured steps. At the Introduction stage, learning instructions, learning objectives and an outline of learning materials are given. This can condition students to be ready to learn both physically and mentally. Readiness to learn is a very important factor and a determinant for successful learning [37].

Connection connects students' prior knowledge with new information through simple presentations and also through various media formats. Furthermore, it presents choices of media or resources developed by the lecturers (learning resources by design) or using available materials (learning resources by utilisation). These include a document (doc), presentation (ppt), animation (swf), video (mpg) and multimedia (exe), which accommodate student modalities. Consequently, this allows students to learn in ways that suit them and promote their activeness [38].

Applications are made to give students the opportunity to practice and apply new knowledge and skills. They work and are active independently through Student Worksheets. These steps lead to maximum student activity to seek and find material (they become study subjects). The results of the research by Yudiawan et al. [39] stated that an online learning system and environment that is student-centred can guarantee the success of learning. Subsequently, students do not become passive recipients but construct their knowledge according to their pace in the learning process. Furthermore, all student activities involve seeking information and answers to their problems, fostering self-confidence and developing higher intellectual abilities [40]. Therefore, these stages can minimise negative activities in online learning.

Reflection is done to check or ensure what students have learned through the presentation of a summary of learning outcomes and giving a measuring quiz with several choices of questions. Quiz given online allows for direct feedback given by the lecturer on the results of student work. Feedback 
is in the form of positive or negative reinforcement from the lecturer. Reflection and feedback allow students to measure their progress, consider alternative learning strategies and project their own further learning needs [41]. The online assessment method and students' access rights to their grades will be able to encourage students to continue to study hard so that they can show good performance in class [42].

Extend is done to strengthen and expand the subject matter that has been completed by reading additional teaching materials, assignments or exercises. This stage also provides opportunities for students to expand the knowledge that has been obtained by challenging wider problems. Yunus et al. [43] stated that the provision of additional teaching materials and their variations in online learning is closely related to students' achievement motivation and can improve students' problem-solving abilities.

This module has also facilitated virtual synchronous learning through video or web conferences. Additionally, it has enhanced personal asynchronous through assignments, quizzes and chats, as well as collaborative interpersonal through online discussion forums and team-based project-based worksheets. There are also variations in delivery and teaching methods, as well as lecturer-student and student-student interactions. These variations provide benefits, such as flexibility, productivity, efficiency and achievement [44], [45]. Similarly, selecting the Moodle LMS application to build an online module has provided several advantages. First, there is flexibility in determining learning activities, such as surveys, communities, journals, assignments, quizzes, choice questions and chats. Second, various formats of learning activities are available, including topic, weekly and social. Third, the module is capable of displaying various user activities. Fourth, all class members on assignments, journals, quizzes and forums are viewed on one page and downloadable as spreadsheet files.

Based on student responses in the trial activity, the online module with the LMS-based ICARE flow in the Learning Media course has clear learning stages and good interactivity. Therefore, it makes students interested and active in the learning process, an indicator of their motivation and a good sign towards improving outcomes [46]. The attractive display elements of this product include the home page, ease of navigation and a harmonious blend of text colours and backgrounds. Additionally, this module in each subject is equipped with pictures, animations, videos and multimedia, helping students or users understand the material better. Enrichment activities (extend) accommodate students with a good speed and completeness in learning.

The ease of using the online module with the LMS-based ICARE flow on this Learning Media course is also recognised by students. They use this module by typing the URL http://elearning.undiksha.ac.id in the browser and accessed with a mobile device or smartphone. Through this module, materials are accessed more quickly, anytime and anywhere. Furthermore, materials enriched with various learning resources, including multimedia, are quickly updated by lecturers. Students also carry out monitoring, communication and cooperation. Additionally, they download materials, take assignments and quizzes and participate in chats and discussion forums. However, despite its many advantages, some obstacles are faced in this online module, especially for students limited to electronic devices, such as PCs, laptops or smartphones, or demand good internet access.

\section{CONCLUSION}

Online learning modules are systematically arranged teaching materials, measurable, attractive and easily understood by users. They are accessed and used without space and time barriers, provided that they are connected to the internet network. Subsequently, these modules are accessed using gadgets, such as cellphones, tablets and PCs or laptops. The online module with an LMS-based ICARE flow in this Learning Media course was developed through analysis, activity design development, learning resources, evaluation and validation from experts. Moreover, the online module was assessed on various aspects, including instructional design, course opening, learning, as well as interaction and community. The other aspects assessed were instructional teaching and learning resources, learner support, technology design, course closing and instructional design cycle. The results were 'Very Good' category, meaning that this product is eligible for application.

\section{CONFLICT OF INTEREST}

The authors declare no conflict of interest.

\section{AUTHOR CONTRIBUTIONS}

IKS developed the idea of research, designed the research instrument and drafted and critically revised the manuscript. LPPM designed the programme mapping, course, activities and resources. DGHD statistically analysed the data. MY prepared the theoretical base of research.

\section{REFERENCES}

[1] L. A. Arasaratnam-Smith and M. Northcote, "Community in online higher education: Challenges and opportunities," Electron. J. e-Learning, vol. 15, no. 2, pp. 188-198, 2017.

[2] C. Vrasidas, I. Pattis, P. Panaou, M. Antonaki, L. Avraamidou, and K. Theodoridou, "Teacher Use of ICT : Challenges and Opportunities," in Proc. the 7th International Conference on Networked Learning 2010 , 2010, pp. 439-445.

[3] G. Basilaia and D. Kvavadze, "Transition to online education in schools during a SARS-CoV-2 coronavirus (COVID-19) pandemic in Georgia,”Pedagog. Res., vol. 5, no. 4, 2020, doi: 10.29333/pr/7937.

[4] M. H. Taha, M. E. Abdalla, M. Wadi, and H. Khalafalla, "Curriculum delivery in Medical Education during an emergency: A guide based on the responses to the COVID-19 pandemic," MedEdPublish, vol. 9, no. 1, 2020, doi: 10.15694/mep.2020.000069.1.

[5] I. K. Suartama, P. Setyosari, Sulthoni, and S. Ulfa, "Development of an instructional design model for mobile blended learning in higher education," Int. J. Emerg. Technol. Learn., vol. 14, no. 16, pp. 4-22, 2019, doi: 10.3991/ijet.v14i16.10633.

[6] I. K. Suartama, P. Setyosari, S. Sulthoni, and S. Ulfa, "Development of ubiquitous learning environment based on moodle learning management system," Int. J. Interact. Mob. Technol., vol. 14, no. 14, pp. 182-204, 2020, doi: 10.3991/ijim.v14i14.11775.

[7] I. K. Suartama, E. Triwahyuni, A. Sukardi, and W. D. Hastuti, "Development of e-learning oriented inquiry learning based on character education in multimedia course," Eur. J. Educ. Res., vol. 9, no. 4, pp. 1591-1603, 2020, doi: 10.12973/eu-jer.9.4.1591.

[8] M. Churiyah, S. Sholikhan, F. Filianti, and D. A. Sakdiyyah, "Indonesia education readiness conducting distance learning in covid-19 pandemic situation," Int. J. Multicult. Multireligious Underst., vol. 7, no. 6, p. 491, 2020, doi: 10.18415/ijmmu.v7i6.1833.

[9] M. Irfan, B. Kusumaningrum, Y. Yulia, and S. A. Widodo, "Challenges during the pandemic: Use of e-learning in mathematics 
learning in higher education," Infin. J., vol. 9, no. 2, p. 147, 2020, doi: 10.22460/infinity.v9i2.p147-158.

[10] N. Yusnilita, "The impact of online learning: Student's views," ETERNAL (English Teach. Journal), vol. 11, no. 1, 2020, doi: 10.26877/eternal.v11i1.6069.

[11] S. Dhawan, "Online learning: A panacea in the time of COVID-19 crisis," J. Educ. Technol. Syst., vol. 49, no. 1, pp. 5-22, 2020, doi: $10.1177 / 0047239520934018$.

[12] M. Adnan, "Online learning amid the COVID-19 pandemic: Students perspectives," J. Pedagog. Res., vol. 1, no. 2, pp. 45-51, 2020, doi 10.33902/jpsp.2020261309.

[13] A. Almonacid-Fierro, R. Vargas-Vitoria, R. S. Carvalho, and M. A. Fierro, "Impact on teaching in times of COVID-19 pandemic: A qualitative study," Int. J. Eval. Res. Educ., vol. 10, no. 2, pp. 432-440, 2021, doi: 10.11591/ijere.v10i2.21129.

[14] S. Hao, V. P. Dennen, and L. Mei, "Influential factors for mobile learning acceptance among Chinese users," Educ. Technol. Res. Dev., vol. 65 , no. 1, pp. 101-123, 2017, doi: 10.1007/s11423-016-9465-2.

[15] N. Dhaliwal, F. Simpson, and A. Kim-Sing, "Self-paced online learning modules for pharmacy practice educators: Development and preliminary evaluation," Curr. Pharm. Teach. Learn, vol. 10, no. 7, pp. 964-974, 2018, doi: 10.1016/j.cpt1.2018.04.017.

[16] I. Anwar, Pengembangan Bahan Ajar. Bahan Kuliah Online, Bandung: Direktori UPI, 2010

[17] J. A. Phillips, "Replacing traditional live lectures with online learning modules: Effects on learning and student perceptions," Curr. Pharm. Teach. Learn., vol. 7, no. 6, pp. 738-744, 2015, doi 10.1016/j.cptl.2015.08.009.

[18] M. Hill, M. D. Sharma, and H. Johnston, "How online learning modules can improve the representational fluency and conceptual understanding of university physics students," Eur. J. Phys., vol. 36, no. 4, 2015, doi: 10.1088/0143-0807/36/4/045019.

[19] M. A. Al Mamun, G. Lawrie, and T. Wright, "Instructional design of scaffolded online learning modules for self-directed and inquiry-based learning environments," Comput. Educ., vol. 144, no. 2020, p. 103695 , 2020, doi: 10.1016/j.compedu.2019.103695.

[20] C. A. Cobb, C. T. Watson, and S. R. Ellis, "Establishing best practices for effective online learning modules: A Single institution study," Med. Sci. Educ., vol. 28, no. 4, pp. 683-691, 2018, doi: 10.1007/s40670-018-0613-7.

[21] K. L. Smart and J. J. Cappel, "Students' perceptions of online learning: A comparative study," J. Inf. Technol. Educ. Res., vol. 5, no. 1, pp. 201-219, 2006, doi: 10.28945/243.

[22] M. Moradi, L. Liu, C. Luchies, M. M. Patterson, and B. Darban, "Enhancing teaching-learning effectiveness by creating online interactive instructional modules for fundamental concepts of physics and mathematics," Educ. Sci., vol. 8, no. 3, 2018, doi 10.3390/educsci8030109.

[23] P. Siahaan, E. Dewi, and E. Suhendi, "Introduction, connection, application, reflection, and extension (ICARE) learning model: The impact on students' collaboration and communication skills," J. Ilm. Pendidik. Fis. Al-Biruni, vol. 9, no. 1, pp. 109-119, 2020, doi: 10.24042/jipfalbiruni.v9i1.5547.

[24] A. Latifa, R. Nur, and A. Rizal, "ICARE learning model in improving the students writing ability," Eralingua J. Pendidik. Bhs. Asing dan Sastra, vol. 4, no. 2, p. 258, 2020, doi: 10.26858/eralingua.v4i2.12850

[25] J. P. M. Perkins, "Using a course management system to improve classroom communication," Sci. Teach., vol. 73, no. 7, pp. 33-37, 2006.

[26] K. Georgouli, I. Skalkidis, and P. Guerreiro, "A framework for adopting LMS to introduce e-learning in a traditional course," vol. 11, no. 2, pp. 227-240, 2008, doi: 10.2307/jeductechsoci.11.2.227.

[27] I. Govender, "The learning context: Influence on learning to program," Comput. Educ., vol. 53, no. 4, pp. 1218-1230, 2009, doi: 10.1016/j.compedu.2009.06.005

[28] J. G. Henderson, "Learning through a disciplined curriculum study approach," Sch. Q., vol. 4, no. 4, pp. 312-315, 2011

[29] S. Chootongchai and N. Songkram, "Design and development of SECI and moodle online learning systems to enhance thinking and innovation skills for higher education learners," Int. J. Emerg. Technol. Learn., vol. 13, no. 3, pp. 154-172, 2018, doi: 10.3991/ijet.v13i03.7991.

[30] W. R. Borg and M. D. Gall, Educational Research. An introduction, 4th ed. New York: Longman, 1983.

[31] W. W. Lee and D. L. Owens, Multimedia Based Instructional Design: Computer Based Training Web Based Training Distance Broadcast Training, Performance Based Solutions, 2nd ed. San Fransisco: Pfeiffer, 2004.
[32] D. F. Walker and R. D. Hess, Instructional Software: Principles and Perspectives for Design and Use, Belmont: Wadsworth Publishing Company, 1984.

[33] M. Debattista, "A comprehensive rubric for instructional design in e-learning," Int. J. Inf. Learn. Technol., vol. 35, no. 2, pp. 93-104, 2018, doi: 10.1108/IJILT-09-2017-0092.

[34] Sukardjo, Evaluasi Pembelajaran. Buku Pegangan Kuliah, PPs Universitas Negeri Yogyakarta, 2010.

[35] D. Salirawati, E. Priyambodo, and M. Primastuti, "The effect of introduction, connection, application, reflection, and extension (ICARE) towards students' chemistry learning outcome," in Proc. 7th Int. Conf. Res. Implementation, Educ. Math. Sci. (ICRIEMS 2020), vol. 528, no. Icriems 2020, pp. 179-187, 2021, doi 10.2991/assehr.k.210305.028.

[36] J. Sinuraya, I. Wahyuni, and D. D. Panggabean, "The ICARE Practice based on worksheet and physics experimental to improve studen creativity," J. Phys. Conf. Ser., vol. 1428, no. 1, 2020, doi 10.1088/1742-6596/1428/1/012048.

[37] L. M. Guglielmino and P. J. Guglielmino, "Learner characteristics affecting success in electronic distance learning," in H.B. Long \& Associates, 21st Century Advances in Self-directed Learning, Schaumburg: Motorola University Press, 2001.

[38] I. K. Suartama, P. Setyosari, Sulthoni, S. Ulfa, M. Yunus, and K. A. Sugiani, "Ubiquitous learning vs. electronic learning: A comparative study on learning activeness and learning achievement of students with different self-regulated learning," Int. J. Emerg. Technol. Learn., vol 16, no. 03, pp. 36-56, 2021.

[39] A. Yudiawan, B. Sunarso, Suharmoko, F. Sari, and Ahmadi, "Successful online learning factors in covid-19 era: Study of islamic higher education in west papua, indonesia," Int. J. Eval. Res. Educ., vol. 10, no. 1, pp. 193-201, 2021, doi: 10.11591/ijere.v10i1.21036.

[40] BADA and S. Olusegun, "Constructivism learning theory: A paradigm for teaching and learning," J. Res. Method Educ., vol. 5, no. 6, pp. 6670, 2015.

[41] W. Bonnel, "Improving feedback to students in online courses," Nurs. Educ. Perspect., vol. 29, no. 5, pp. 290-294, 2008.

[42] D. G. H. Divayana, I. G. Sudirtha, and I. K. Suartama, "Digital test instruments based on wondershare - superitem for supporting distance learning implementation of assessment course," Int. J. Instr., vol. 14 no. 4, pp. 945-964, 2021, doi: 10.29333/iji.2021.14454a.

[43] M. Yunus, P. Setyosari, S. Utaya, and D. Kuswandi, "The influence of online project collaborative learning and achievement motivation on problem-solving ability," Eur. J. Educ. Res., vol. 10, no. 2, pp. 813823, 2021, doi: 10.12973/EU-JER.10.2.813.

[44] R. D. Araújo, T. Brant-Ribeiro, I. E. S. Mendonça, M. M. Mendes, F. A. Dorça, and R. G. Cattelan, "Social and collaborative interactions for educational content enrichment in ULEs," Educ. Technol. Soc., vol. 20, no. 3, pp. 133-144, 2017

[45] Munawaroh, "The influence of teaching methods and learning environment to the student's learning achievement of craft and entrepreneurship subjects at vocational high school," Int. J. Environ. Sci. Educ., vol. 12, no. 4, pp. 665-678, 2017.

[46] K. Demir and E. Akpinar, "The effect of mobile learning applications on students' academic achievement and attitudes toward mobile learning," Malaysian Online J. Educ. Technol., vol. 6, no. 2, pp. 48-59, 2018 .

Copyright $\odot 2022$ by the authors. This is an open access article distributed under the Creative Commons Attribution License which permits unrestricted use, distribution, and reproduction in any medium, provided the original work is properly cited (CC BY 4.0).

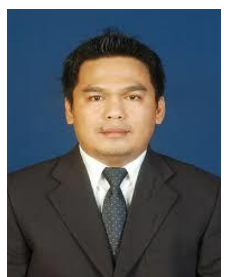

I Kadek Suartama is a doctor in the field of educational technology. He currently teaches at Universitas Pendidikan Ganesha, Singaraja, Indonesia. His research interests are learning design and learning media including e-learning, multimedia learning and mobile learning.

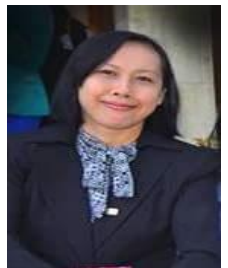

Luh Putu Putrini Mahadewi is a doctorate student in educational technology at the Universitas Negeri Jakarta. She currently teaches at Universitas Pendidikan Ganesha, Singaraja, Indonesia. Her research interests are learning strategies and media. 


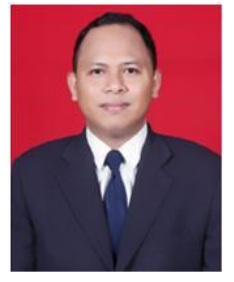

Dewa Gede Hendra Divayana is a doctor in the field of educational evaluation. He currently teaches at Universitas Pendidikan Ganesha, Singaraja, Indonesia.

His research interest is the evaluation of information

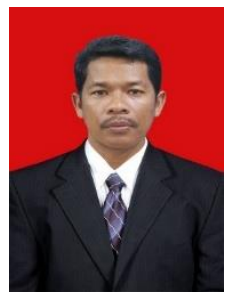

Muhammad Yunus is a doctor in the field of educational technology. He currently teaches at Universitas Syiah Kuala, Banda Aceh, Indonesia. His research interests are instructional design and instructional media. 